\title{
2 Histopathological effects and biomarker response of earthworms, 3 Eisenia fetida, after exposure to crude oil contaminated soils
}

${ }^{1}$ Environmental Biology Unit, Department of Cell Biology and Genetics, University of Lagos, Akoka, Lagos, Nigeria. ${ }^{2}$ Chemical Science Department, Yaba College of Technology, Yaba, Lagos, Nigeria.

${ }^{3}$ Molecular Biology Unit, Department of Cell Biology and Genetics, University of Lagos, Akoka, Lagos, Nigeria.

*Correspondence: biologistalex@gmail.com

Received: January 18, 2020 Accepted: September 22, 2020

\begin{abstract}
Earthworms are the most abundant invertebrates in the soils and are permanently in close contact with soil particles. Therefore, they are significantly affected by the pollutants that reach the soil system. The study was aimed at evaluating the effect of exposure to crude oil contaminated soil on Eisenia fetida using cellular antioxidant enzymes and tissue organization as biomarkers. E. fetida were exposed to different concentrations of crude oil contamination of $1 \mathrm{~mL}, 2 \mathrm{~mL}$. and $3 \mathrm{~mL}(0.25,0.50$ and $0.75 \%)$ for 14 days. The antioxidant/oxidant parameters were analysed in the muscle and liver tissues. The results showed that only the reduced glutathione (GSH) of earthworms exposed to $1 \mathrm{~mL}$ were not significant ( $p>0.05$ ) from the control, while the other concentrations $(2 \mathrm{~mL}-0.50 \%$ and $3 \mathrm{~mL}-0.75 \%$ ) were significantly different $(\mathrm{p}<0.05)$ from the control. The activity of catalase (CAT) with respect to the total protein content was highest in the liver of earthworms exposed to $1 \mathrm{~mL}(0.25 \%$ conc.) on day $7(51.84 \mu \mathrm{mol} / \mathrm{mg}$ pro) while the least CAT activity with respect to the total protein content was reported in the liver of control earthworms after 14 days $(19.51 \mu \mathrm{mol} / \mathrm{mL} / \mathrm{min})$. A significant increase in the activity of superoxide dismutase at all the concentrations $(0.25,0.50$ and $0.75 \%)$ after 14 days were also observed. Significant histopathological alterations were observed in E. fetida from the three concentrations. Severe disruptions in the arrangement of their body wall muscle layers, distorted internal viscera, as well as cellular degeneration, pigments, moderate to severe areas of lesion, and distortion of the shape of circular and longitudinal muscles, eroding of internal and external tissues leading to total destruction of body wall were observed. In conclusion, the study revealed that crude oil even at lower concentration induced biomarker responses in E. fetida such as higher levels of Malondialdehyde in E. fetida after exposure crude oil due its toxicity. Histopathological alterations such as cellular degeneration, moderate to severe areas of necrosis, areas of inflammation, inclusion bodies, pigments, and distortion of the shapes of circular and longitudinal muscles also showed the adverse impacts of crude oil pollution in the soils.
\end{abstract}

Keywords: Earthworm, crude oil, hydrocarbon, histopathology, Biomarker, E. fetida

\section{Introduction}

In the last few decades, soil pollution has vastly increased owing to the intensive industrial and agricultural activities, overpopulation, urban waste and atmospheric deposition causing decrease in soil fertility, modification of soil structure, disturbance flora and fauna balance in the soil, accumulation of pollutants in the crops, and contamination of groundwater [1-3]. These chemical pollutants include heavy metals, pesticides, herbicides, ammonia, petroleum hydrocarbons, polychlorobiphenyl, dibenzo-p-dioxins/dibenzofurans, nitrate, mercury, and naphthalene [4,5]. Globally, petroleum-related activities have raised concerns about the adverse effects of contamination of petroleum products on the environment [6]. Petroleum hydrocarbons are of environmental interest because they are toxic to the human system, plants, and animal resources. Hitherto, they pervade the environment beyond the localities of petroleum exploration and production activities due to storage, disposal, and other handling activities during which contamination of the environment sometimes occur [3,7].

Petroleum hydrocarbons do not decompose easily and do not disappear from the soil even if their sources to the environment are contained or restricted. Therefore, their effects on soil organisms and decomposition processes persist for 
many years. Soil pollution by petroleum hydrocarbons usually originates from spills or leaks of storage tanks during fuel supply and discharge operations. Petroleum hydrocarbons include aliphatic and aromatic compounds; some of them are known or suspected human carcinogens and are classified as priority pollutants [8,9]. However, due to the increasing concern about petroleum hydrocarbons pollution of soil, there is an increasingly international and scientific interest in monitoring and assessment of soil pollution. The old-style approach to soil pollution assessment, based on the analysis of the concentrations of pollutants in the soil and comparison with specific threshold values, does not indicate deleterious effects of contaminants on the biota [10]. For these reasons, new biological approaches to soil monitoring, such as the measurement of biochemical and cellular responses to pollutants (biomarkers) on organisms living in the soil (bioindicators), have become of major importance for the assessment of the quality of this environmental compartment [11].

Biomarkers can be used as a complementary approach to standard toxicity tests to examine the effects of contaminant toxicity on living organisms at earlier stages and lower concentrations [12]. It has been reported that the contaminant stress in living organisms often results in the production of reactive oxygen species (ROS). The overproduction of ROS such as hydrogen peroxide $\left(\mathrm{H}_{2} \mathrm{O}_{2}\right)$ and superoxide radicals cause oxidative stress and produces useless molecular debris and sometimes cell death [13]. Ideally, biochemical biomarkers will identify effects at the subcellular level before they are apparent at higher levels of biological organization [14]. Furthermore, the exposure of organisms to pollutants also induces some lesions in different organs which can act as histopathological markers when biological systems are exposed to hydrocarbon related stressors [15].

Soil invertebrates may represent good sentinel organisms of soil chemical pollution because they are in direct contact with soil pore water or food exposure, in contrast to many vertebrates that are indirectly exposed through the food chain [16]. Earthworms are ecologically important for their role in soil maintenance and health through their abundance, their role in decomposition and soil texture improvement, and their key position in terrestrial food chains [17-19]. The earthworms are suitable organisms for soil ecotoxicological research because of their particular interactions with soil, they are significantly affected by pollutants reaching the soil system [20]. Earthworms can be exposed to contaminants in various ways. First, living in the soil by having direct contact with soil pore water and therefore with pollutants therein dissolved. The earthworm skin is extremely permeable to water and it represents the main route for contaminant uptake [21]. Also, these organisms ingest large amounts of soil, therefore been continuously exposed to contaminants adsorbed to solid particles through their alimentary tract [22]. Chemical uptake via the dermal route can also directly related to the pore water concentration. All these make them one of the utmost suitable bioindicator organisms for risk assessment in soils [20].

Biomarkers have been primarily used in earthworms experimentally exposed to polluted environments. Several studies have shown that pollutants can induce an increase in ROS in earthworms [14, 23, 24]. Induction or inhibition of the antioxidant enzymatic system is considered valid biomarkers of environmental pollution in earthworm toxicology [25]. The exposure of organisms to pollutants also induces several lesions in different organs which can act as histopathological markers when biological systems are exposed to petroleum-product related stressors [14]. However, the effects of crude oil exposure on earthworms' E. fetida biomarkers have not been reported. In this study we focused on the earthworm, E. fetida, an epigeic species, using selected stress biomarkers like superoxide dismutase (SOD), catalase (CAT), reduced glutathione (GSH) and lipid peroxidation (LPO) and their changes in histology. The study aims to systematically investigate biomarker responses of earthworms, E. fetida, and their histopathological effects after exposure to soils experimentally contaminated by crude oil.

\section{Materials and methods \\ Source of materials}

Topsoil sample used for this experiment was collected within 1 to $10 \mathrm{~cm}$ depth from the nursery site of the Zoological and Botanical garden of the University of Lagos, Akoka which is situated in the North-East of Yaba, Lagos State, Nigeria. It lies in the latitude $6031^{\prime} 0 \mathrm{~N}$ and longitude $3023^{\prime} 10^{\prime \prime}$ E. Cultured E. fetida with well-developed clitella were purchased from the Department of Zoology, University of Lagos, Lagos, Nigeria. Prior to the experiments, the earthworms were acclimatised in samples of the non-polluted soil for 14 days at room temperature. Also, the earthworms were allowed to depurate their gut contents onto moistened filter paper for $24 \mathrm{~h}$. Adult (with clitellum) earthworms, each weighing 0.45$0.55 \mathrm{~g}$ were used in the experiments. The crude oil (Wellhead medium) was obtained from Shell Petroleum Development Company (SPDC) Port Harcourt, Nigeria.

\section{Contamination composition and experimental setup}

Three different soil concentrations were prepared for this study. The soil samples were mixed with $1 \mathrm{~mL}, 2 \mathrm{~mL}$ and $3 \mathrm{~mL}$ of crude oil to give concentrations of $0.25 \%, 0.50 \%$ and $0.75 \%$ respectively. However, the control samples were left uncontaminated $(0 \%)$. These uncontaminated soils served as the control for this study. Twenty E. fetida were placed in each small plastic bowls (pots) containing $1 \mathrm{~kg}$ of soil. Each pot contained soils samples that were of either the three prepared concentrations or the control. Each concentration was setup in triplicates (three pots each). In total, 12 pots were set in the 
Ijomah et al. I Biomarker responses and histopathological effects of soils contaminated with crude oil

study. The experiment was conducted for a total of 14 days. Hence, the earthworms were exposed to these conditions throughout the experiment. During the exposure, the earthworms were fed with cow manure spread on the soil surface. However, after seven days, three E. fetida were removed from each pot, rinsed with ultrapure water, and allowed to depurate for $24 \mathrm{~h}$ before further biochemical and histopathological analysis. Furthermore, after 14 days, three earthworms (from each pot) were also removed, rinsed and depurated for $24 \mathrm{~h}$ before being taken for analysis.

\section{Measurement of antioxidant and oxidants parameters in the earthworms}

Each of the selected earthworms was cut open and sliced. The organs were then dissected, and the liver and gills were removed, the fleshes of the animal were also cut. The post mitochondria fraction of the organs of the animal was prepared as follows: The organs of the animal were washed in an ice cold $1.15 \% \mathrm{KCl}$ solution, blotted and weighed. They were then homogenized with $0.1 \mathrm{M}$ phosphate buffer ( $\mathrm{pH}$ 7.2), putting the organs each into the mortar; laboratory sand was added to it (acid washed sand) and it was blended in the mortar with pestle together. The resulting homogenate was centrifuged at $2500 \mathrm{rpm}$ for $15 \mathrm{mins}$ then it was removed from the centrifuge and the supernatant was decanted and stored $-20{ }^{\circ} \mathrm{C}$ until analysis.

The organ homogenate was then used to determine the activities of the following antioxidant enzymes. SOD activity was determined by its ability to inhibit the auto-oxidation of epinephrine determined by the increase in absorbance at $480 \mathrm{~nm}$ as described by Sun and Zigma [26]. CAT activity was determined according to Sinha [27]. Serum CAT activity was determined according to the method of Beers and Sizer as described by Usoh et al. [28] by measuring the decrease in absorbance at $240 \mathrm{~nm}$ due to the decomposition of in a $\mathrm{H}_{2} \mathrm{O}_{2} \mathrm{UV}$ recording spectrophotometer. The reduced $\mathrm{GSH}$ content of the liver tissue as non-protein sulphydryls was estimated according to the method described by Sedlak and Lindsay [29]. Malondialdehyde (MDA), an index of LPO was determined using the method of Buege and Aust [30]. The protein was determined using biuret method [31] and bovine serum albumin (BSA) as standard.

\section{Histopathological assay}

Each of the selected earthworm was cut open and sliced. Tissue samples from the body wall and viscera were cut and placed inside a labelled tissue embedding cassette. The cassette was then placed in a 24-hour automatic tissue processor for 18-hour for complete processing. The processing involves complete fixation in formal saline solution, chemical dehydration and finally embedding in molten paraffin wax. After the wax has hardened, the embedded sample was cut with the microtome. Sections cut from the sample was then placed on a clean grease free slide for viewing under the microscope. Before viewing, the slides were stained using the $\mathrm{H}$ and $\mathrm{E}$ (Haematoxylin and Eosin) staining method to demonstrate the general structure of the tissue. The slide is then viewed microscopically and the tissue structures between each concentration and the control were compared.

\section{Statistical analysis}

All values are presented as means \pm standard deviation (SD). In enzyme assays, t-tests and one-way analysis of variance (ANOVA) followed by the least significant difference (LSD) test was employed to evaluate the statistical significance $(p<0.05)$ of the results between exposed samples and the control group by SPSS 22.0.

\section{Results and Discussion}

\section{Biochemical response of Eisenia fetida exposed to various concentration of crude oil}

Numerous researchers on animals have established the significance of antioxidants in defending and protecting the cellular systems from oxidative stress induced by electromagnetic fields, chemicals and toxicants [14, 15, 32, 33]. Antioxidant enzyme activity may increase or decrease under the pressure of the pollutant; however, this depends on the strength, force, concentration and length of the stress applied, in addition to the sensitivity or tolerance of the exposed organisms. Changes in activities of antioxidant enzymes and LPO products can be an indication of oxidative stress.

GSH, one of the major tripeptide non-enzymatic biological antioxidants present in the liver, it is associated with the removal of free radicals and maintenance of membrane protein and thiols, and a substrate for GPx [34]. Deficiency of GSH within the living organisms can lead to tissue damage and injury [35]. The reduced GSH content of the liver of E. fetida is presented in Table 1. The reduced GSH content with respect to the total protein content reduced generally from decreased from the initial day to the end of the study. The GSH reduction in day 7 and 14 was significant $(p<0.05)$ for all the concentration level. This reduction is due to over-utilization to challenge the prevailing oxidative stress. However, when the organisms consumed excessive GSH, more GSH would be synthesized as the adaptation to the environmental stress [36]. On the day 7 , it was observed that the GSH contents were significantly $(\mathrm{p}<0.05)$ higher in the pollutant exposed earthworms than in the control. Furthermore, the highest reduced GSH content was recorded on the day 14 of earthworms exposed to 1 $\mathrm{mL}$ of pollutant.

Also on day 14, it was observed that only the reduced GSH of earthworms exposed to $1 \mathrm{~mL}$ were not significant 
( $p>0.05$ ) from the control, while the others concentration $(2 \mathrm{~mL}-0.50 \%$ and $3 \mathrm{~mL}-0.75 \%)$ were significantly different $(\mathrm{p}<0.05)$ from the control. The decrease of the GSH content at day 14 could be attributed to the inhibition of antioxidant enzyme activities under long-term contaminant stress. Similar result was reported by Saliu and Bawa-Allah [32] who also observed a reduction in GSH values of fishes exposed to lead salts. This suggests an adaptive and protective role of the biomolecule (GSH) against oxidative stress caused by the presence of the constituent compounds.

CAT is an enzymatic antioxidant extensively distributed in all animal tissues which help decomposes hydrogen peroxide and protects the tissue from highly reactive hydroxyl radicals [37]. CAT activity varies greatly from tissue to tissue, the highest activity is found in liver and kidney, and the least activity in the connective tissue [38]. Inhibition of this enzyme may enhance sensitivity to free radical-induced cellular damage. Earthworms through their skins and alimentary surfaces are continuously exposed to chemicals in the soil. Hence, they have a reliable detoxification system for them to survive [39].

The activity CAT of the liver of the earthworms, E. fetida is presented in Table 2. The activity of CAT with respect to the total protein content was highest in the liver of earthworms exposed to $1 \mathrm{~mL}(0.25 \%$ conc.) on day $7(51.84 \mu \mathrm{mol} / \mathrm{mg}$ pro) while the least CAT activity with respect to the total protein content was reported in the liver of control earthworms after 14 days $(19.51 \mu \mathrm{mol} / \mathrm{mL} / \mathrm{min})$. At the end of the study, CAT activity of $1 \mathrm{~mL}(0.50 \%$ conc) and $3 \mathrm{~mL}(0.75 \%$ conc) earthworms were observed to be significantly above $(\mathrm{p}<0.05)$ the control level, while the $2 \mathrm{~mL}$ others was not significant from that of the control $(\mathrm{p}>0.05)$. The increase in the activity of CAT may be triggered by the generation of $\mathrm{H}_{2} \mathrm{O}_{2}$, while the reduction in the activity of CAT may result in hydrogen peroxide assimilation. CAT is known to breakdown hydrogen peroxide which is a free radical, into water and molecular oxygen. The pattern of CAT activity is similar to that of Eudrilus eugeniae exposed to monocyclic aromatic hydrocarbons in oil impacted site reported by Doherty et al. [14].

Many hydrocarbons components present in crude oil require efficient elimination of metabolic oxidation; their long-term exposure could lead to oxidative stress [40]. Biochemical responses of organisms to environmental stress are regarded as early warning indices of pollution in the environment. The SOD activity in the liver of the earthworms, E. fetida are presented in Table 3 . The result showed that after seven days, SOD activity with respect to the total protein content ( $\mu \mathrm{mol} / \mathrm{mg}$ pro) was found to be significantly higher $(\mathrm{p}<0.05)$ in the liver of the earthworms exposed to $3 \mathrm{~mL}$ of pollutant, while it was significantly $(\mathrm{p}<0.05)$ lower in earthworms exposed to $2 \mathrm{~mL}$ of pollutant. However, after 14 days the ratio was significantly $(\mathrm{p}<0.05)$ higher in earthworms exposed to $2 \mathrm{~mL}$ of pollutant.

This study showed a significant increase in the activity of SOD at all the concentrations $(0.25,0.50$ and $0.75 \%)$ after 14 days, suggesting the formation of $\mathrm{O}_{2}$, which incites oxidative stress-related responses. Similar results were reported in a study performed by Han et al. [41], in which, after exposure of azoxystrobin to zebrafish, SOD activities decreased significantly in liver as compared to control. Induction of antioxidant enzyme activities is attributed to a saturation of antioxidant defences of the cell against ROS, indicating high oxidative stress [42]. SOD is one of the most responsive enzymes against ROS. SOD catalyses the conversion of reactive $\mathrm{O}_{2}-$ to produce $\mathrm{H}_{2} \mathrm{O}_{2}$, which is subsequently detoxified by CAT [43]. In this study, the two biomarkers showed a similar response pattern. During the experiment, the activities of both SOD and $\mathrm{CAT}$ in the earthworms were induced, indicating that the crude oil induced the generation of superoxide radicals after entering into the earthworms. The SOD activity therefore needed to be enhanced to catalyze the superoxide radicals into $\mathrm{H}_{2} \mathrm{O}_{2}$, which further induced the CAT activity. However, under long-lasting contamination conditions, the antioxidant enzyme activities, such as SOD and CAT may be deactivated with an accumulation of the oxidizing agent [44].

Table 1. The reduced glutathione (GSH) content of earthworms in the study

\begin{tabular}{|c|c|c|c|c|c|c|c|c|}
\hline \multirow[b]{2}{*}{ Days } & \multicolumn{4}{|c|}{$\begin{array}{l}\text { Total liver GSH content with respect to the total protein } \\
\text { content ( } \mu \mathrm{mol} / \mathrm{mg} \text { pro) }\end{array}$} & \multicolumn{4}{|c|}{$\begin{array}{l}\text { Total liver GSH content } \\
(\mu \mathrm{mol} / \mathrm{mL} / \mathrm{min})\end{array}$} \\
\hline & $\begin{array}{l}0.25 \% \\
(1 \mathrm{~mL})\end{array}$ & $\begin{array}{l}0.50 \% \\
(2 \mathrm{~mL})\end{array}$ & $\begin{array}{l}0.75 \% \\
(3 \mathrm{~mL})\end{array}$ & Control & $\begin{array}{l}0.25 \% \\
(1 \mathrm{~mL})\end{array}$ & $\begin{array}{l}0.50 \% \\
(2 \mathrm{~mL})\end{array}$ & $\begin{array}{l}0.75 \% \\
(3 \mathrm{~mL})\end{array}$ & Control \\
\hline 7 & 3.30 & 2.40 & 4.35 & 2.60 & 37.40 & 43.80 & 42.10 & 33.50 \\
\hline 14 & 2.45 & 1.95 & 1.85 & 1.65 & 39.20 & 24.50 & 28.10 & 33.00 \\
\hline
\end{tabular}

Table 2. Catalase (CAT) activity of earthworms in the study

\begin{tabular}{|c|c|c|c|c|c|c|c|c|}
\hline \multirow[b]{2}{*}{ Days } & \multicolumn{4}{|c|}{$\begin{array}{l}\text { Total liver CAT activity with respect to the total protein } \\
\text { content ( } \mu \mathrm{mol} / \mathrm{mg} \text { pro) }\end{array}$} & \multicolumn{4}{|c|}{$\begin{array}{l}\text { Total liver CAT activity } \\
(\mu \mathrm{mol} / \mathrm{mL} / \mathrm{min})\end{array}$} \\
\hline & $\begin{array}{l}0.25 \% \\
(1 \mathrm{~mL}) \\
\end{array}$ & $\begin{array}{l}0.50 \% \\
(2 \mathrm{~mL}) \\
\end{array}$ & $\begin{array}{l}0.75 \% \\
(3 \mathrm{~mL}) \\
\end{array}$ & Control & $\begin{array}{l}0.25 \% \\
(1 \mathrm{~mL}) \\
\end{array}$ & $\begin{array}{l}0.50 \% \\
(2 \mathrm{~mL}) \\
\end{array}$ & $\begin{array}{l}0.75 \% \\
(3 \mathrm{~mL})\end{array}$ & Control \\
\hline 7 & 51.84 & 31.50 & 37.50 & 50.00 & 590.00 & 585.00 & 393.00 & 693.50 \\
\hline 14 & 42.00 & 23.00 & 46.00 & 19.51 & 730.65 & 415.00 & 680.00 & 430.00 \\
\hline
\end{tabular}


Ijomah et al. I Biomarker responses and histopathological effects of soils contaminated with crude oil

LPO is a biomarker for oxidative damage. MDA formation is associated with the reactions of unsaturated fatty acids and free radicals in cellular membranes and is considered to be an important sensitive indicator of LPO and indicates intracellular injury [45,46]. Various contaminants are known to induce LPO due to excessive ROS [32, 33,47].

The MDA index of the liver of E. fetida was also determined with respect to the total protein content (Table 4). After seven days, this ratio was found to be significant $(\mathrm{p}<0.05)$ higher in the liver of the earthworms exposed to $3 \mathrm{~mL}$ of crude oil $(0.75 \%)$ than that of the control. In this study, MDA contents in control earthworms were significantly $(p<0.05)$ lower than those of the earthworms exposed to crude oil for all the concentrations, in increasing order, with the earthworms exposed to $3 \mathrm{~mL}(0.75 \%)$ having the highest value $(0.50 \mu \mathrm{mol} / \mathrm{mg}$ pro). Also, after 14 days the MDA of the control earthworms had the lowest MDA content $(0.09 \mu \mathrm{mol} / \mathrm{mg}$ pro $)$, which was significantly lower $(\mathrm{p}<0.05)$ than the MDA of the crude oil exposed earthworms indicating that the crude oil had induced oxidative toxicity which far exceeded the protective capacity of the antioxidant defence system and caused actual damage. The results from this study are similar to the findings of Saint-Denis et al. [23], who reported higher levels of MDA in E. fetida after day 14 of exposure to lead suggesting high production of ROS. This is also consistent with the findings of Otitoloju and Olagoke [48] and Avci et al. [49] who reported an increase in MDA levels in tissues of fishes exposed to petroleum hydrocarbons.

\section{Histopathological changes in the body of E. fetida exposed to various concentration of crude oil}

Histopathological changes in earthworms have been identified as important markers of toxicity $[14,39]$. Hydrocarbons can impact earthworms through ingestion of contaminated litter in the soil and exposure to the skin. These chemicals can get to the coelomic fluid through the skin and can be distributed all over the body of the organisms. The tissue samples from the body wall and viscera were viewed and compared with those of the control earthworms. Careful examination of the control samples collected after 7 days showed that the histologic section of the body wall muscle layers was intact and well-arranged. Additionally, their internal viscera were all well outlined, no lesion, no necrosis, no pigments, no malignancy, no inflammation, and no inclusion bodies (Figure 1A).

Earthworms' histologic changes after exposure to $1 \mathrm{~mL}, 2 \mathrm{~mL}$ and $3 \mathrm{~mL}(0.25 \%, 0.50 \%$, and $0.75 \%$ crude oil) revealed induced marked histopathological changes in the body of the earthworms (Figure 1B and 1D). The changes disruption of the wall muscle layers, cellular degeneration, pigments, moderate to severe areas of lesion, and distortion of the shape of circular and longitudinal muscles, eroding of internal and external tissues leading to total destruction of body wall were observed. Mild lesion and disruption of the wall of the muscle layers were observed in the tissues of the $2 \mathrm{~mL}$ samples $(0.50 \%)$. Tissues of E. fetida exposed to $0.75 \%$ crude oil $(3 \mathrm{~mL})$ revealed them to have undergone the worse disruptions in their body wall muscle layers and severe tissue disorganization after 7 days

Table 3. Superoxide Dismutase (SOD) activity of earthworms in the study

\begin{tabular}{|c|c|c|c|c|c|c|c|c|}
\hline \multirow[b]{2}{*}{ Days } & \multicolumn{4}{|c|}{$\begin{array}{l}\text { Total liver SOD activity with respect to the total protein } \\
\text { content ( } \mu \mathrm{mol} / \mathrm{mg} \text { pro) }\end{array}$} & \multicolumn{4}{|c|}{$\begin{array}{l}\text { Total liver SOD activity } \\
(\mu \mathrm{mol} / \mathrm{ml} / \mathrm{min})\end{array}$} \\
\hline & $\begin{array}{l}0.25 \% \\
(1 \mathrm{~mL}) \\
\end{array}$ & $\begin{array}{l}0.50 \% \\
(2 \mathrm{~mL}) \\
\end{array}$ & $\begin{array}{l}0.75 \% \\
(3 \mathrm{~mL}) \\
\end{array}$ & Control & $\begin{array}{l}0.25 \% \\
(1 \mathrm{~mL})\end{array}$ & $\begin{array}{l}0.50 \% \\
(2 \mathrm{~mL}) \\
\end{array}$ & $\begin{array}{l}0.75 \% \\
(3 \mathrm{~mL})\end{array}$ & Control \\
\hline 7 & 6.35 & 6.50 & 6.80 & 4.50 & 73.00 & 66.00 & 69.50 & 63.00 \\
\hline 14 & 5.40 & 7.20 & 7.20 & 4.80 & 83.50 & 91.50 & 93.10 & 64.10 \\
\hline
\end{tabular}

Table 4. Malondialdehyde (MDA), an index of lipid peroxidation (LPO), of earthworms in the study

\begin{tabular}{|c|c|c|c|c|c|c|c|c|}
\hline \multirow[b]{2}{*}{ Days } & \multicolumn{4}{|c|}{$\begin{array}{l}\text { Total liver MDA index with respect to the total protein } \\
\text { content ( } \mu \mathrm{mol} / \mathrm{mg} \text { pro) }\end{array}$} & \multicolumn{4}{|c|}{$\begin{array}{l}\text { Total liver MDA index } \\
\qquad(\mu \mathrm{mol} / \mathrm{mL})\end{array}$} \\
\hline & $\begin{array}{l}0.25 \% \\
(1 \mathrm{~mL}) \\
\end{array}$ & $\begin{array}{l}0.50 \% \\
(2 \mathrm{~mL})\end{array}$ & $\begin{array}{l}0.75 \% \\
(3 \mathrm{~mL})\end{array}$ & Control & $0.25 \%(1 \mathrm{~mL})$ & $\begin{array}{l}0.50 \% \\
(2 \mathrm{~mL})\end{array}$ & $\begin{array}{l}0.75 \% \\
(3 \mathrm{~mL})\end{array}$ & Control \\
\hline 7 & 0.23 & 0.28 & 0.50 & 0.17 & 3.00 & 4.40 & 5.25 & 2.20 \\
\hline 14 & 0.29 & 0.11 & 0.39 & 0.09 & 2.10 & 2.30 & 3.90 & 1.40 \\
\hline
\end{tabular}



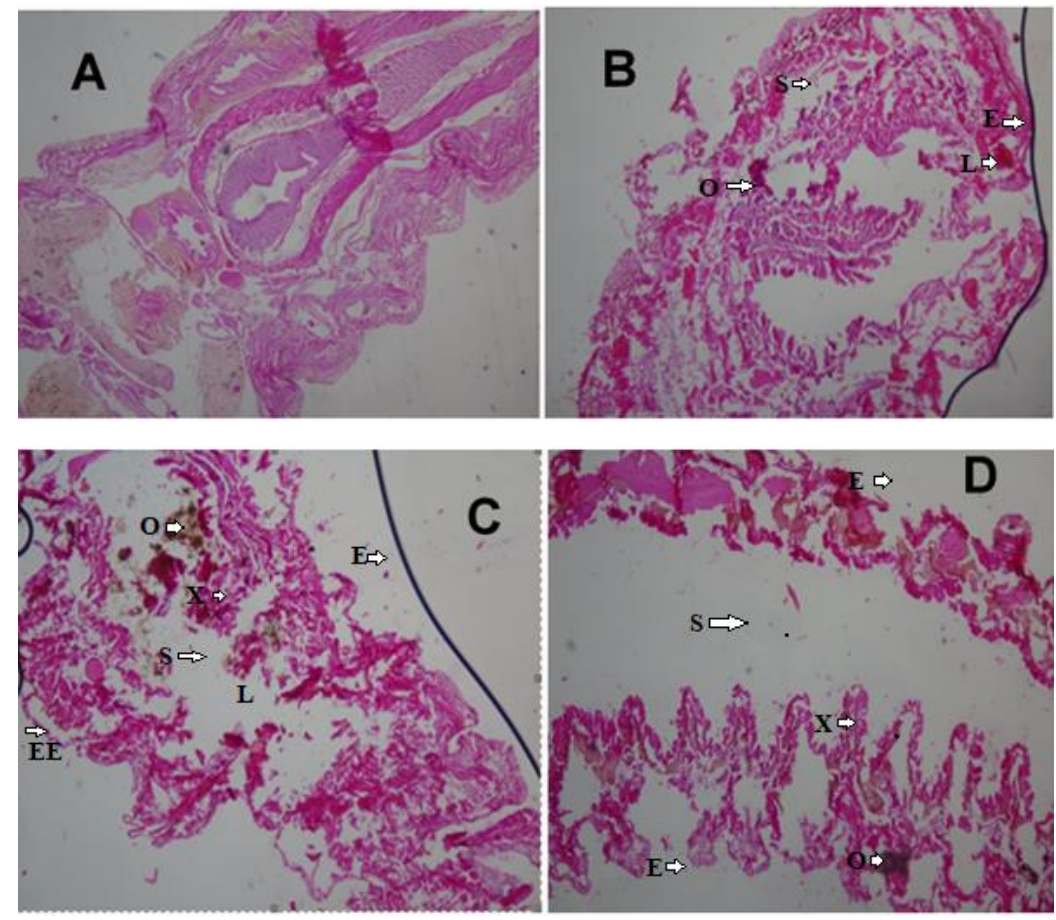

Figure 1: Histopathological effects of crude oil exposure on Eisenia fetida after 7 days (H\&E x 400). (A) Control samples; (B) $1 \mathrm{~mL}$ samples (0.25\%); (C) $2 \mathrm{~mL}$ samples (0.50\%); (D) $3 \mathrm{~mL}$ samples (0.75\%).

NOTES: $\mathrm{S}$ = Spaces between longitudinal and circular muscles; $\mathrm{O}=$ Dark brown pigment; $\mathrm{L}=$ Lesion area; $\mathrm{E}=$ Distortion in the muscle wall; $\mathrm{EE}=$ Enlargement of ectoderm cells; $\mathrm{X}$ : Cellular degeneration

After 14 days, the histologic view of the control (Figure 2A and 2B) showed that they had a normally well arranged body wall muscle layers and a well outlined internal viscera. Thus, these worms have normal tissue organization. However, $1 \mathrm{~mL}$ $(0.25 \%)$ earthworm samples (Figure 2C and 2D) had mild lesion and tissue disorganisation. However, the histology analysis of the $2 \mathrm{~mL}(0.50 \%)$ (Figure $3 \mathrm{~A}$ and $3 \mathrm{~B}$ ) and the $3 \mathrm{~mL}(0.75 \%)$ earthworm samples (Figure 3C and 3D) showed that they had severe disruptions in the arrangement of their body wall muscle layers and well distorted internal viscera, as changes disruption of the wall muscle layers, cellular degeneration, pigments, moderate to severe areas of lesion, and distortion of the shape of circular and longitudinal muscles, eroding of internal and external tissues leading to total destruction of body wall were observed. Hence, they have a severe tissue disorganisation. Doherty et al. [14] reported sub-lethal levels of benzene, toluene, ethylbenzene and xylene (BTEX) compounds induced pathological changes in the body of the earthworms (E. eugeniae) including cellular degeneration, moderate to severe areas of necrosis, areas of inflammation, inclusion bodies, pigments, and distortion of the shapes of circular and longitudinal muscles as observed in this study. Kilic [39] also detected enlargement of epithelial cell lining, necrosis, and loss of structural integrity of circular and longitudinal muscles in Lumbricus terrestris in polluted soil. Bansiwal and Rai [50] also observed similar result as they observed obvious pathological changes which include ruptured cuticle and distortion of shape of muscles after exposure of earthworm to Malathion. ROS produced by exposure to hydrocarbons are responsible for the various histopathological changes noted in this study. According to Saint-Denis et al. [23] ROS and inflammation induce cellular necrosis E. fetida andrei exposed to lead acetate contaminated artificial soil. Also, the swelling of the cells and disruption of the plasma membrane are the initial stages of necrosis. The core processes of necrosis are bioenergetic failure and rapid loss of plasma membrane integrity [14]. 
Ijomah et al. I Biomarker responses and histopathological effects of soils contaminated with crude oil

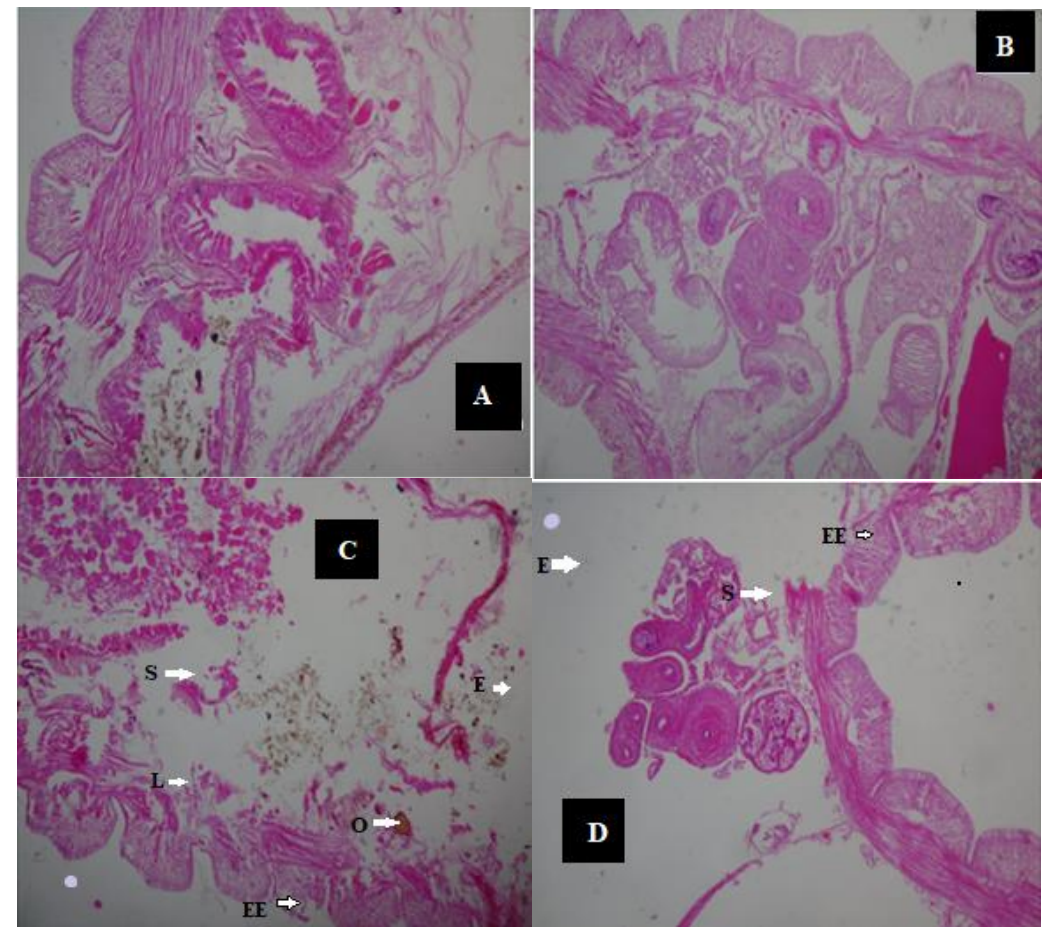

Figure 2: Histopathological effects of crude oil exposure on Eisenia. fetida after 14 days (H\&E x 400). (A) Control samples; (B) control samples; (C) $1 \mathrm{~mL}$ samples (0.25\%); (D) $1 \mathrm{~mL}$ samples $(0.25 \%)$.

NOTES: $\mathrm{S}=$ Spaces between longitudinal and circular muscles; $\mathrm{O}=$ Dark brown pigment; $\mathrm{L}=$ Lesion area; $\mathrm{E}=$ Distortion in the muscle wall; $\mathrm{EE}=$ Enlargement of ectoderm cells; $\mathrm{X}$ : Cellular degeneration
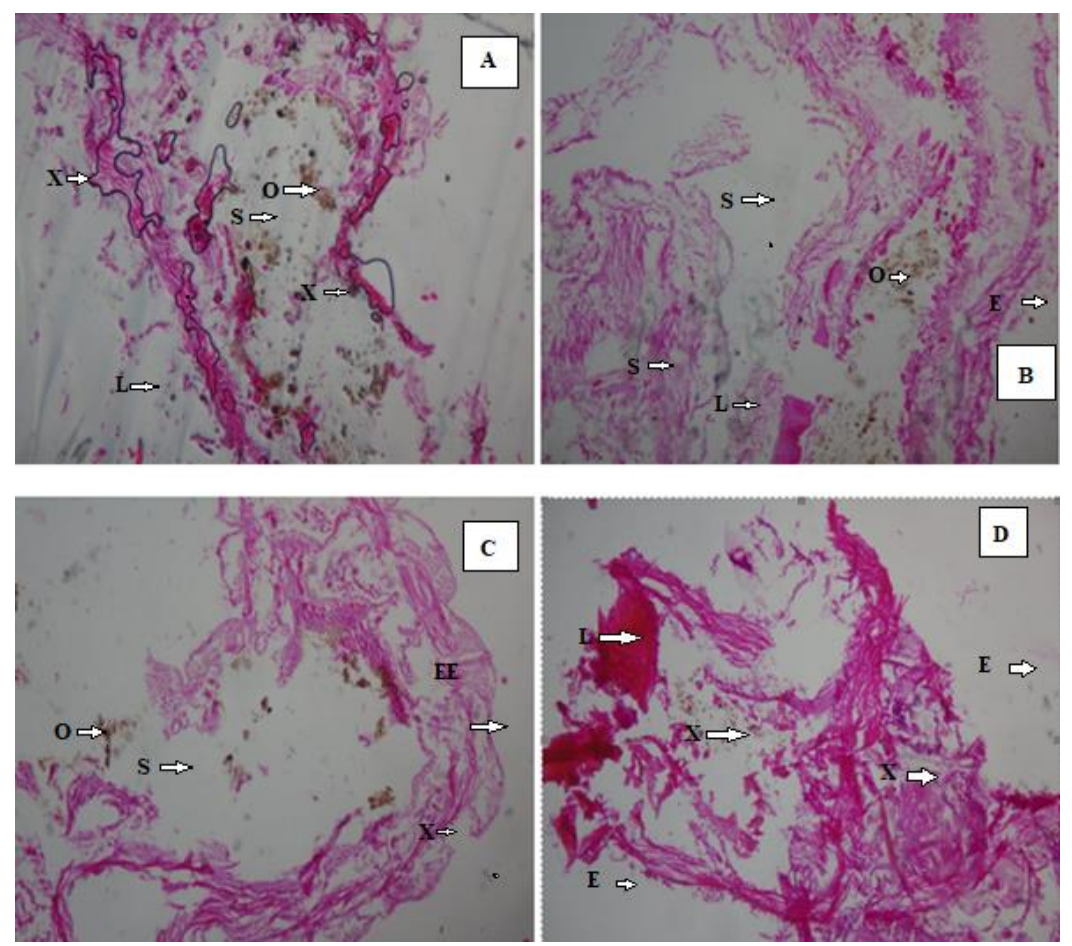

Figure 3: Histopathological effects of crude oil exposure on Eisenia. fetida after 14 days (H\&E x 400). (A) $2 \mathrm{~mL}$ samples (0.50\%) (B) $2 \mathrm{~mL}$ samples (0.50\%) (C) $3 \mathrm{~mL}$ samples $(0.75 \%)$ (D) $3 \mathrm{~mL}$ samples (0.75\%).

NOTES: $\mathrm{S}=$ Spaces between longitudinal and circular muscles; $\mathrm{O}=$ Dark brown pigment; $\mathrm{L}=$ Lesion area; $\mathrm{E}=$ Distortion in the muscle wall; $\mathrm{EE}=$ Enlargement of ectoderm cells; $\mathrm{X}$ : Cellular degeneration 


\section{Conclusions}

In conclusion, the study revealed that crude oil induced biomarker responses in E. fetida such as higher levels of MDA in E. fetida after exposure crude oil due its toxicity. Histopathological markers including cellular degeneration, moderate to severe areas of necrosis, areas of inflammation, inclusion bodies, pigments, and distortion of the shapes of circular and longitudinal muscles also showed the adverse impacts of crude oil pollution in soils.

\section{Acknowledgement}

The Authors appreciate Shell Petroleum Development Company in Port Harcourt for the provision of crude oil used for this study.

\section{Conflict of interest}

Researchers declare that there is no conflict of interest.

\section{CRediT author statement}

OI: Conceptualization, Methodology, Investigation, Software, Writing- Original draft preparation; AA: Conceptualization, Methodology, Investigation, Data curation, Software, Supervision, Writing- Reviewing and Editing; KN: Conceptualization, Methodology, Investigation, Supervision; SO: Methodology, Investigation, Data curation; UM: Methodology, Investigation, Software; OA: Visualization, Data curation, Writing- Reviewing and Editing.

\section{ORCID}

Adeola Alex Adesuyi: 0000-0001-8887-7357

\section{References}

[1] Adesuyi AA, Njoku KL, Akinola MO. Assessment of Heavy Metals Pollution in Soils and Vegetation around Selected Industries in Lagos State, Nigeria. J Geosci Environ Prot 2015;3:11-19.

[2] Adesuyi AA, Njoku KL, Akinola MO, Jolaoso AO. Biomonitoring of Heavy Metals Level in Wetland Plants of Lagos Lagoon, Nigeria. JASEM 2018;22(9):1489-1498.

[3] Jolaoso AO, Njoku KL, Adedokun AH, Adesuyi AA. Assessment of Automobile Mechanic Workshop Soils in Lagos and the Genotoxic Potential of the Stimulated Leachate using Allium cepa. J Environ Qual 2019;34:48-62.

[4] Capri E, Trevisan M. I Metalli Pesanti di Origine Agricola nei Suoli e nelle Acque Sotterranee. 1st ed. Pitagora Editrice; 2002.

[5] Mustapha N, Njoku KL, Adesuyi AA, Jolaoso AO. Evaluating Genotoxic Effects of Plants Exposed to Heavy Metals and Polycyclic Aromatic Hydrocarbons at Dumpsite, Mechanic Workshop and Metal Scrap Site in Lagos. JASEM 2019;23(2):335-341.

[6] Njoku KL, Yussuf A, Akinola MO, Adesuyi AA, Jolaoso AO, Adedokun AH. Mycoremediation of Petroleum Hydrocarbon Polluted Soil by Pleurotus pulmonarius. EJESM 2016;9(1):865-875.

[7] Iwegbue CMA, Nwajei ES, and Williams GE. Characteristic levels of total petroleum hydrocarbon in soil profiles of automobile mechanic waste dumps. Int J Soil Sci 2008;3(1):48-51.

[8] Adetunde OT, Mills GA, Olayinka KO, lo BI. Bioaccessibility-Based Risk Assessment of PAHs in Soils from Sites of Different Anthropogenic Activities in Lagos, Nigeria Using the Fed Organic Estimation Human Simulation Test Method. Soil Sediment Contam 2018;27(6):501-512.

[9] Brewster CS, Sharma VK, Cizmas L, McDonald TJ. Occurrence, distribution and composition of aliphatic and polycyclic aromatic hydrocarbons in sediment cores from the Lower Fox River, Wisconsin, US. Environ Sci Pollut Res Int 2018;25(5):4974-4988.

[10] Criel P, Lock K, Eeckhout HV, Oorts K, Smolders E, Janssen CR. Influence of soil properties on copper toxicity for two soil invertebrates. Environ Toxicol Chem 2008;27(8):1748-1755.

[11] Kammenga JE, Dallinger R, Donker MH, Köhler HR, Simonsen V, Triebskorn R, et al. Biomarkers in terrestrial invertebrates for soil risk assessment. Rev Environ Contam Toxicol 2000;164:93-147. 
Ijomah et al. I Biomarker responses and histopathological effects of soils contaminated with crude oil

[12] Schreck E, Geret F, Gontier L, Treilhou M. Neurotoxic effects and metabolic responses induced by a mixture of six pesticides on the earthworm Aporrectodea caliginosa nocturna. Chemosphere 2008;71(10):1832-1839.

[13] Dazy M, Masfaraud JF, Ferard JF. Induction of oxidative stress biomarkers associated with heavy metal stress in Fontinalis antipyretica Hedw. Chemosphere 2009;75(3):297-302.

[14] Doherty FV, Aneyo I, Otitoloju AA. Histopathological and biochemical alterations in Eudrilus eugeniae (Kinberg 1867) as biomarkers of exposure to monocyclic aromatic hydrocarbons in oil impacted site. J Basic Appl Zool 2019; 80(1):63.

[15] Valavanidis A, Vlahogianni T, Dassenakis M, Scoullos M. Molecular biomarkers of oxidative stress in aquatic organisms in relation to toxic environmental pollutants. Ecotoxicol Environ Saf 2006;64(2):178-189.

[16] Kammenga JE, Spurgen DJ, Svendsen C, Weeks JM. Explaining Density-Dependent Regulation in Earthworm Populations Using Life-History Analysis. Oikos 2003;100(1):89-95.

[17] Vijver MG, Vink JPM, Miermans CJH, van Gestel CAM. Oral sealing using glue: a new method to distinguish between intestinal and dermal uptake of metals in earthworms. Soil Biol Biochem 2003;35(1):125-132.

[18] Le Roux S, Baker P, Crouch A. Bioaccumulation of total mercury in the earthworm Eisenia andrei. SpringerPlus 2016;5(1):681.

[19] Njoku KL, Akinola MO, Anigbogu CC. Vermiremediation of Soils Contaminated with Mixture of Petroleum Products using Eisenia fetida. J Appl Sci Environ Manage 2016;20(3):771-779.

[20] Wang Z, Cui Z. Accumulation, biotransformation, and multi-biomarker responses after exposure to arsenic species in the earthworm Eisenia fetida. Toxicol Res 2016;5(2):500-510.

[21] Calisi A, Lionetto MG, De Lorenzis E, Leomanni A, Schettino T. Metallothionein induction in the coelomic fluid of the earthworm Lumbricus terrestris following heavy metal exposure: a short report. Biomed Res Int 2014;109386.

[22] Morgan AJ, Stürzenbaum SR, Winters C, Grime GW, Aziz NA, Kille P. Differential metallothionein expression in earthworm (Lumbricus rubellus) tissues. Ecotoxicol Environ Saf. 2004;57(1):11-19.

[23] Saint-Denis M, Narbonne JF, Arnaud C, Ribeira D. Biochemical responses of the earthworm Eisenia fetida andrei exposed to contaminated artificial soil: effects of lead acetate. Soil Biol Biochem 2001;33:395-404.

[24] Xiao N, Song Y, and Ge F. Biomarkers responses of the earthworm Eisenia fetida to acetochlor exposure in OECD soil. Chemosphere 2006;65(6):907-912.

[25] Song Y, Zhu LS, Wang J, Wang JH, Liu W, Xie H. DNA damage and effects on antioxidative enzymes in earthworm (Eisenia foetida) induced by atrazine. Soil Biol Biochem 2009;41(5):905-909.

[26] Sun M, Zigma S. An improved spectrophotometric assay of superoxide dismutase based on ephinephrine antioxidation. Anal Biochem 1978;90(1):81-89.

[27] Sinha AK. Colorimetric assay of catalase. Anal Biochem 1972;47(2):389-394.

[28] Usoh IF, Akpan EJ, Etim EO, Farombi E. Antioxidant Actions of Dried Flower Extracts of Hibiscus sabdariffa L. on Sodium arsenile Induced Stress in Rats. Pak J Nutri 2005;4(3):135-141.

[29] Sedlak J, Lindsay RH. Estimation of total, protein-bound, and nonprotein sulfhydryl groups in tissue with Ellman's reagent. Anal Biochem 1968;25:192-205.

[30] Buege JA, Aust SD. Microsomal lipid peroxidation. Meth Enzymol 1978;52:302-310.

[31] Gornall AG, Bardawill CJ, David MM. Determination of serum proteins by means of the biureto reaction. J Biol Chem 1949;177:751-766.

[32] Saliu JK, Bawa-Allah KA. Toxicological effects of Lead and Zinc on the antioxidant enzyme activities of post juvenile Clarias gariepinus. Resour Environ 2012;2(1):21-26.

[33] Aderemi S, Njoku KL, Adesuyi AA. The effect of Electromagnetic Radiation (EMR) from Laptop on Reproductive Hormones, Sperm Quality and Prostate Specific Antigen of Male Albino Rats (Rattus norvegicus). Ecological Safety and Balanced Use of Resources 2019;19(1):43-52. 
[34] Balamurugan M, Parthasarathi K, Ranganathan LS, Cooper EL. Hypothetical mode of action of earthworm extract with hepatoprotective and antioxidant properties. J Zhejiang Univ Sci B 2008;9(2):141-147.

[35] Kawamura T, Muraoka I. Exercise-Induced Oxidative Stress and the Effects of Antioxidant Intake from a Physiological Viewpoint. Antioxidants 2018;7(9):119.

[36] van der Oost R, Beyer J, Vermeulen NP. Fish bioaccumulation and biomarkers in environmental risk assessment: a review. Environ Toxicol Pharmacol 2003;13(2):57-149.

[37] Kurutas EB. The importance of antioxidants which play the role in cellular response against oxidative/nitrosative stress: current state. Nutr J 2016;15(1):71.

[38] Merghem M, Dahamna S, Khennouf S. In Vivo Antioxidant Activity of Ruta montana L. Extracts. J Mater Environ Sci 2019;10(5):470-477.

[39] Kilic AK. Histopathological and biochemical alterations of earthworm (Lumbricus terrestris) as biomarker of soil pollution along porsuk river basin (Turkey). Chemosphere 2011;83(8):1175-1180.

[40] Karnjanapiboonwong A, Morse AN, Maul JD, Anderson TA. Sorption of estrogens, triclosan, and caffeine in a sandy loam and a silt loam soil. J Soil Sediment 2010;10:1300-1307.

[41] Han Y, Liu T, Wang J, Wang J, Zhang C, Zhu L. Genotoxicity and oxidative stress induced by the fungicide azoxystrobin in zebrafish (Danio rerio) livers. Pest Biochem Physiol 2016;133:13-19

[42] Koivula MJ Eeva T. Metal-related oxidative stress in birds. Environ Pollut 2010;158(7):2359 -2370.

[43] Wan R, Meng F, Fu W, Wang Q, Su E. Biochemical responses in the gills of Meretrix meretrix after exposure to treated municipal effluent. Ecotoxicol Environ Saf 2015;111:78-85.

[44] Modesto KA, Martinez CB. Roundup causes oxidative stress in liver and inhibits acetylcholinesterase in muscle and brain of the fish Prochilodus lineatus. Chemosphere 2010;78(3):294-299.

[45] Grundy JE, and Storey KB. Antioxidant defenses and lipid peroxidation damage in estivating toads, Scaphiopus couchii. J Comp Physiol 1998;168:132-142.

[46] Cao Q, Steinman AD, Yao L, Xie L. Toxicological and biochemical responses of the earthworm Eisenia fetida to cyanobacteria toxins. Sci Rep 2017;7(1):1-9.

[47] Vasilaki AT, McMillan DC. Lipid Peroxidation. In: Schwab M, editor. Encyclopedia of Cancer. Springer; 2011.

[48] Otitoloju AA, Olagoke O. Lipid peroxidation and antoxidant defense enzymes in Clarias gariepinus as useful biomarkers for monitoring exposure to polycyclic aromatic hydrocarbons. Environ Monit Assess 2011;182(1-4):205213.

[49] Avci A, Kaçmaz M, Durak I. Peroxidation in muscle and liver tissues from fish in a contaminated river due to a petroleum refinery industry. Ecotoxicol Environ Saf 2005;60(1):101-105.

[50] Bansiwal K, Rai N. Assessment of malathion toxicity in certain organs of earthworm, Eisenia foetida. The Bioscan 2010;5(3):473-476. 